\title{
The Procedure For Resolving Individual Labour Disputes In Uzbekistan, Post-Soviet Countries And Some Developed Countries. Comparative-Legal Analysis
}

\author{
Lola Rahimqulova, Tashkent State University of Law, Republic of Uzbekistan , l.rahimqulova@tsul.uz, \\ https://orcid.org/0000-0002-2181-5773
}

\begin{abstract}
This article explains in detail the procedure for resolving individual labour disputes in Uzbekistan. The reasons why individual labour disputes are arising will be discussed. The role and significance of the International Labor Organization's Recommendations №92 and №130 in the national labor legislation of Uzbekistan will be paid attention. The procedure for resolving labour disputes arising by alternative ways will be analyzed. Practical and theoretical problems of consideration and settlement of individual labour disputes in a special body - the Labour Disputes Commission will be analyzed. Alternative labour dispute resolution in French and German labour legislation has been studied from a comparative-legal point of view. The process of resolving individual labor disputes through mediation will also be analyzed. The peculiarities of resolving individual labor disputes in the judicial system of Uzbekistan will be analyzed. As a result, theoretical and practical solutions for the effective and shortterm settlement of individual labor disputes in Uzbekistan will be proposed.
\end{abstract}

Keywords: labour, labor dispute, woman rights, employee, employer, labour relations, voluntary.

Received: 07.12.2020 $\quad$ Accepted: 16.01.2021 $\quad$ Published: 03.02.2021

\section{INTRODUCTION}

The number of individual disputes arising from day-to-day workers' grievances or complaints has been rising across countries and regions. The causes are complex, and vary across countries and regions. Minawa Ebisui, Sean Cooney and Colin Fenwick as a result of the study of the labour market of the member states of the International Labour Organization, cited the following common features as the reasons for the occurrence of labour disputes:

$>\quad$ an increased range of individual rights protections;

$>$ Decrease in trade union density and/or collective bargaining coverage

$>$ Higher risks of termination of employment and unemployment

$>\quad$ Redused job quality and security due to greater use of various contractual arrangements for employment and other forms of work

$>\quad$ Increased inequality as a result of segmented labour markets [1]

The increase in number and varity of individual disputes has given rise to a wide range of challenges.

The current economic reforms carried out intensively in Uzbekistan are leading to an increase in the number of various disagreements, contradictions in social relations, particularly in labour relations. For example, according to one of the official social networks, employees of Enter Engineering, one of the giant companies operating in the oil sector in Uzbekistan, protested on October 21, 2020 and caused great damage to the property of the company. [2] The objective and subjective reasons caused the protest between the employees. The settlement procedure of individual labour disputes in Uzbekistan is established by laws. They effectively and rapidly restore the violated labour rights and protect the property and other non-property interests of participants in labour relations in a timely way.

The government of Uzbekistan is drafting and implementing a number of legal norms to improve alternative dispute resolution. Particularly, the Law of the Republic of Uzbekistan On Mediation adopted on June 3, 2018[3] and the Resolution of the President of the Republic of Uzbekistan On measures to further improve the mechanisms of alternative dispute resolution adopted on June 17, 2020 serves as a legal basis for creating an open space to discuss matters out of the court. [4]

\section{METHODOLOGY}

As components of the methodology, the author used general scientific methods, which involve the study of all phenomena and processes in their development, interconnection and interdependence, as well as special methods. In particular, the methods of dialectical materialism, system analysis, analysis and 
synthesis, logical, historical, comparative-legal, formal-legalwere used .

\section{DISCUSSION}

Since Uzbekistan has lived under the Soviet regime for almost 70 years, the history of labour legislation in independent Uzbekistan is closely linked to that of the former Soviet jurisprudence.

In the history of the former Soviet Union, we can observe that Soviet ideology after the Second World War profoundly affected the concepts of labour law as well as labour disputes. During that period there was a popular expression, «the one who doesn't work doesn't bite». For the first time it was adopted in 1918 in Article 18 of the Constitution of the USSR. This concept sounded as "if you are not a worker, then you cannot eat". It, consolidated as the constitutional level, has evoked a sense of complete justification of forced labour among the population. Previously, the institution of forced labour was seen as the recruitment of the unemployed class, while in the period of military communism, it was seen as a social nationwide recruitment. [5]

As the head of the USSR I.V.Stalin called as follows: capitalism must be abolished, and the notions of a system of exploitation, a conflict of interests in mental and physical labour relations, must be completely abolished. Moreover, these notorious notions have been eradicated in the modern socialist country we are building. In turn, there can be no disagreements among the boss and the person engaged in manual labour, on the contrary, they are "friends" acting together for the prosperity of the enterprise. [6] From these points it is not difficult to understand the state policy on conflicts and disputes arising in labour relations. In the history of the former USSR, the causes of labour disputes and conflicts as well as their settlement procedure were not widely covered. Even if they occured, they were hidden from the public as much as possible, and by this way they tried to form a society of "friendly and united" workersservants in the eyes of the world community.

In the early years of its independence, Uzbekistan joined the International Labour Organization in 1992 and has now ratified 17 conventions of this organization. [7]

The conventions and recommendations of the International Labour Organization recommend establishing a mechanism for reviewing and resolving individual labour disputes arising within the territory of the enterprise (organization, institution).

We also consider the role of collective voice mechanisms in resolving individual disputes: these may be trade unions or other workes' representatives or their bodies, such as works councils. The role of collective mechanisms reflects principles found in ILO Recommendations Nos 92 and 130. These call for: (a) participation/representation of workers and employers on equal footing as a cornerstone of joint machinery for voluntary conciliation and grievance procedures; and (b) emphasis on dispute prevention, which is associated with finding voluntary solutions and settlements of disputes freely aceepted by the worker and the employer.

Recommendation № 130 para. 17 also contemplates "procedures provided for by collective agremeents" and /or "voluntary arbitration by a person or persons designated with the agreement of the employer and worker concerned or their respective organizations" as possible procedures for final settlement of grievances. [8]

Uzbekistan, as a full member, is also following the recommendations of the International Labour Organization, and taking measures to effectively implement the provisions in the national labour legislation. Although the Republic of Uzbekistan has not ratified the Recommendations № 92 and № 130 of the International Labour Organization until today, their recommendary guidelines have been expressed in the national labour legislation.

The mechanisms for resolving labour disputes in the labour legislation of most post-Soviet countries are almost identical. For example, Chapter 15 of the Labour Code of the Russian Federation, [9] Chapter 15 of the Labour Code of the Republic of Kazakhstan, [10] Chapter 14 of the Labour Code of the Republic of Tajikistan, [11] Chapter 14 of the Labour Code of the Republic of Turkmenistan, [12] Chapter 42 of the Labour Code of the Kyrgyz Republic , [13] Chapter 17 of the Labour Code of the Republic of Belarus, [14] Chapter 15 of the Labour Code of Ukraine, [15] Chapter 15 of the Labour Code of the Republic of Uzbekistan stipulates that individual labour disputes shall be resolved by Labour Disputes Commission and court. [16] However, in some states labour laws, the Labour Disputes Commission is not directly referred to as the body that reviews and resolves labour disputes. Particularly, Article 294 of Chapter 45 of the Labour Code of the Republic of Azerbaijan defines the possibility of establishing a special body for pre-trial consideration and resolution of individual labour disputes in collective agreements. [17]

Article 259 of the Labour Code of the Republic of Uzbekistan defines the notion of individual labour disputes. According to it, individual labour disputes are disagreements between the employer and a worker with regard to the application of legislative and other normative acts on labour and labour 
conditions provided for by the labour contract.

The following are reasons of arising individual labour disputes in Uzbekistan:

- $\quad$ Different interpretations of labour law;

- Incompleteness in labour legislation;

- Inadequate legal awareness and legal knowledge of officials representing the employer and the worker;

- Enforcement of minimum employment conditions (under legislation, or an award or agreement);

- Termination of employment (unfair dismissal);

- Discrimination on the basis of other protected attributes such as race, colour, sexual preference, age, physical or mental disability, marital status, pregnancy, political opinion and social origin

- Workplace bullying;

The procedure for resolving individual labour disputes in Uzbekistan:

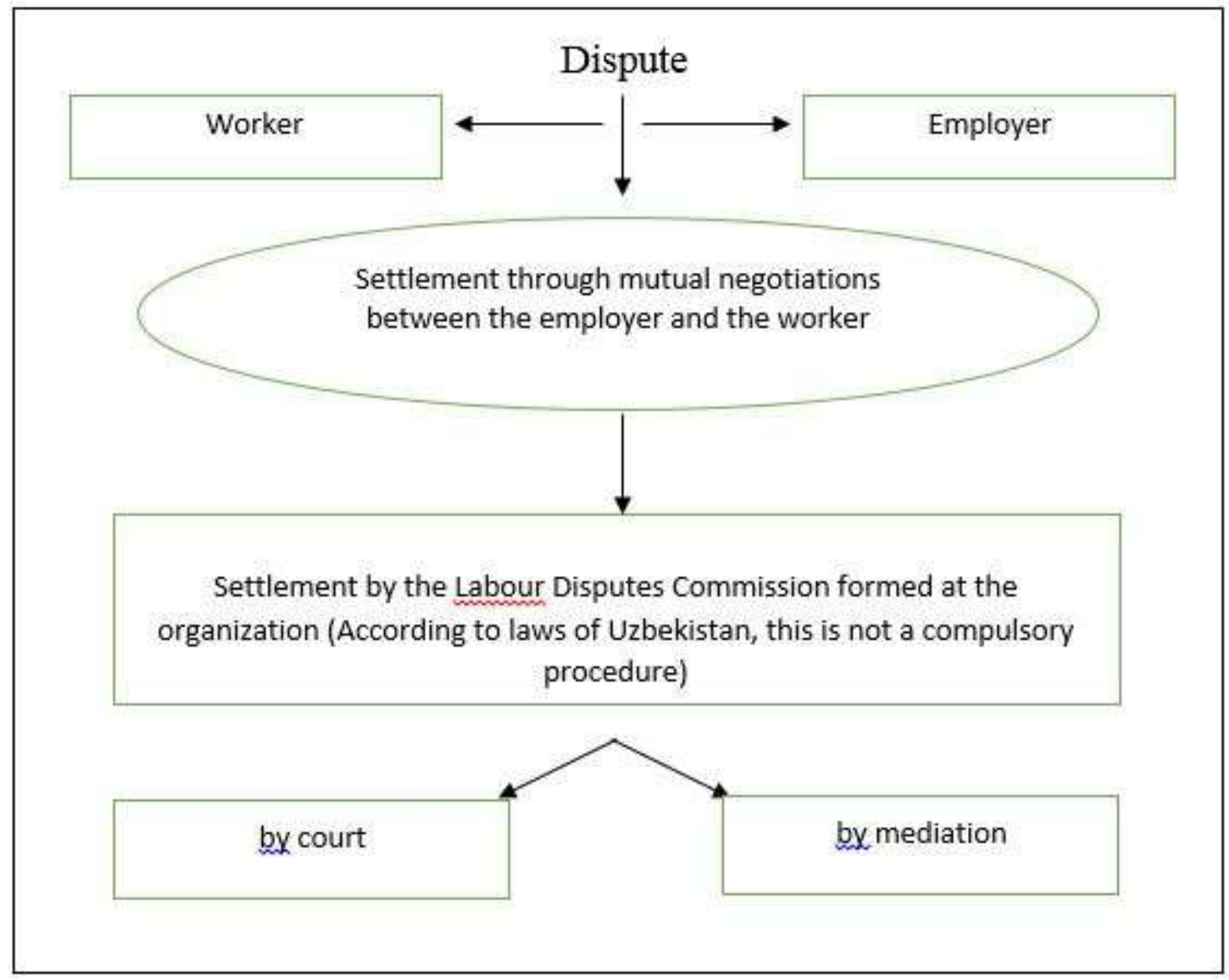

The following legal norms regulate alternative resolution ways of the labour disputes:

- Relevant norms of the current Labour Code of the Republic of Uzbekistan regulating the activity of the Labour Disputes Commission.

- Law On mediation adopted in 2018. [18]

The country has a mechanism for resolving labour disputes on the territory of the enterprise. Thus, the labour legislation of Uzbekistan and post-Soviet countries stipulates that the Labour Disputes Commission is a special labour jurisdiction body that settles labour disputes within a single enterprise or organization and can be formed within each enterprise.

The procedure for resolving individual labour disputes by the Labour Disputes Commission in enterprises and organizations can be directly established by the Labour Code of the Republic of Uzbekistan and the Regulations on the Labour Disputes Commission which are adopted jointly by the employer and the wokers and attached to the collective contract, or in the local regulations of the enterprise. Both the representative bodies of the workers and the employer may take the initiative (proposal) to establish this commission. The Labour Disputes Commission is formed on the basis of 
mutual equality of the workers and the employer's representation in terms of numbers, namely equal number of members on both sides. [19]

The members of the Labour Disputes Commission, who are representatives of the employer and workers, have equal rights and powers. The commission operates independently, and even will have its own seal. The employer is obliged to create the necessary conditions for the effective operation of this commission (for example, a separate room, communications and transport), and not to interfere in its activities. However, the Uzbek Labour Code (as in the labour laws of Tajikistan, Turkmenistan, Kazakhstan, Kyrgyzstan, Russia, Belarus, and Ukraine) does not specify which types of individual labour disputes should be settled by the Labour Disputes Commission.

Unfortunately, today there is no primary role of this commission to settle labour disputes in Uzbekistan. Moreover, its current activities are very inefficient. We came to this conclusion through the evaluation based on the statistics of the highest state body regulating labour relations in the territory of Uzbekistan - the Ministry of Employment and Labour Relations of the Republic of Uzbekistan in 20152020. According to it, none of the labour disputes was settled by the Labour Disputes Commission established on the territory of the enterprise (organization, institution).[20]

In Russian this type of mechanism for settling labour disputes is outdated. Today establishing special labour courts and legal regulation of their activities remains an actual topic among Russian scholars. [21]

Workplace employee representation is a common institutional feature of industrial relations in the EU, albeit diverse in form and practice.

In France, a company with 11 or more employees must have elected employee representatives. A company with 50 or more employees must also have union representatives, appointed by one or more representative unions. These representation mechanisms play a role in encouraging internal resolution of individual labour disputes. In practice, over the 50 percent of companies and establishments with more than 50 employees have union representatives. Moreover, the majority of individual disputes that go before ETs come from small companies, without formal union structures. Furthermore, the unions are authorized, in certain cases and subject to certain conditions, in their name and on their behalf, through the dispute remains individual, taking into account the vulnerability of certain categories of employees or protection of fundamental human rights. Nowadays, In France, the unions may intervene as direct representatives of employees falling into one of a dozen different categories.

In Germany, internal grievance procedures for the private sector are regulated under the Work Constitution Act, which stipulates that employees have the right to raise a grievance and participate in the workplace. Employees can raise a grievance directly, either individually or by seeking assistance or mediation through the relevant workplace body or works council. In the event of a disagreement between the works council and the employer on whether the grievance is well founded, the works council (not the employee) may take the matter to conciliation committee, comprising equal numbers of members of members nominated by, respectively, the employer and the works council, and an impartial third party agreed between the parties.

In Sweden, trade unions are granted formal powers by law to represent their members and those covered under collective agreements ( 90 per cent of employees) in the resolution of individual labour disputes, which must first be negotiated fully before the labour court. While some unions are working to address the representational challenge, in the meantime unorganized workers are left to take their individual disputes to the ordinary district courts.

In Canada, unions have a duty to represent their members in filing their grievances with employers. Grievance procedures are set out in collective agremeents, but are regulated in general terms by legislation. But there is a marked difference between union involvement in grievances in the private sector, and in the public sector.

Another example is Japan. In Japan, joint consultation between employers and enterprise-based unions has played a role in building harmonious labour-management relations and in preventing and resolving workplace conflicts. Long-term employment practices and seniority -based wage system have also worked as an incentive for workers to avoid disputes. However, this practice and its associated effects have weakened with an increase in the number of non-standard workers, who tend to be excluded both from traditional corporate practices and from union representation.

In the United States, labour arbitration mechanisms established through collective agreements provide bipartite procedures in the unionized context, but apply exlusively to the unionized workforce (approximately 11 per cent in total, and only around 6 per cent in the private sector)-a small minority of the total workforce. The parties agree on private arbitrators, who conduct arbitration in cases involving violations of the agreements and in individual grievance cases initiated by unions. Arbitrators' decisions are generally binding and final. However, the process is slow, formal, costly and complex. Thus 
employers bound by collective agreements sometimes use grievance mediation by third parties as a step before arbitration, or simplify the procedures [22].

Currently, almost all legal matters are being effectively settled by mediation around the world, and have already produced its positive results in the settlement of disputes in a short term. The procedure for resolving legal matters with the help of a mediator has been introduced in almost all postSoviet countries. The Law on Mediation was adopted in Ukraine (2015), [23] in the Russian Federation [24] and the Republic of Kazakhstan (2014), [25] in Belarus (2013), [26] in Moldova [27] and in the Kyrgyz Republic (2017). [28]

Mediation is one of the alternative dispute resolution form for settling labour disputes in Uzbekistan. It has not been long since the disputing parties have approached a mediator to consider and resolve a matter arising in social life. The Law On Mediation adopted in 2018 is the only legal document in Uzbekistan regulating mediation activities and its establishment. The scope of mediation is stipulated in Article 3 of this Law.

This Law applies to relations involving the use of mediation in disputes arising from civil law relations, including in connection with business activities, as well as individual labour disputes and disputes arising from family law relations, unless otherwise provided by law. Mediation is applied on the basis of the will of the parties. Mediation can be applied out of court, in the process of consideration of the dispute in court, before the court is removed to a separate (advisory) room for the adoption of a judicial act, as well as in the process of execution of judicial acts and acts of other bodies.

The activity of a mediator in Uzbekistan can be carried out on a professional or nonprofessional basis.

A person who has completed a special training course on a training program for mediators approved by the Ministry of Justice of the Republic of Uzbekistan and also entered into the Register of Professional Mediators can carry out mediator activity on a professional basis. Special training courses on a training program for mediators will be organized by the Center for Alternative Dispute Resolution based on the mutual joining of professional mediators, arbitration courts and international arbitrations, as well as Center for Training of Lawyers under the Ministry of Justice of the Republic of Uzbekistan and Center for Professional Training of Legal Personnel according to international standards at the Tashkent State University of Law. Special training courses is carried out on a full-time basis by a contract for no more than 72 hours.

A person who has attained the age of twenty-five years and who has agreed to perform the duties of a mediator may carry out the activity of a mediator on a non-professional basis.

Undoubtedly, most labour disputes and conflicts arising in domestic labour relations are considered and resolved by district (city) courts within the scope of the legislation of Uzbekistan.

According to the Article 8 of the Labour Code the defence of labour rights which is effectuated by supervision and control agencies over compliance with legislation on labour, and also agencies for the consideration of labour disputes, shall be guaranteed to each citizen.

Article 44 of the Constitution of the Republic of Uzbekistan stipulates that everyone shall be entitled to legally defend his rights and freedoms, and shall have the right to appeal any unlawful action of state bodies, officials and public associations. [29] However, constitutional rights of citizens of Uzbekistan, foreign nationals or stateless persons to participate in the fair settlement of individual and collective labour disputes in the competent state bodies is not guaranteed at the constitutional level.

Part 4 of Article 37 of the Constitution of the Russian Federation [30] and Part 3 of Article 24 of the Constitution of the Republic of Kazakhstan establish the rights of individuals and communities to settle labour disputes as fundamental constitutional rights. [31]

Preamble of the Constitution of the Republic of Uzbekistan establishes that the people of Uzbekistan recognize priority of the generally accepted norms of the international law. This similar rule is also reflected in the labour legislation. According to it, foreign citizens have the right to appeal to the courts of the Republic of Uzbekistan in the manner prescribed by national labour legislation, unless otherwise provided by international treaties and agreements of the Republic of Uzbekistan.

Stateless persons also have the right to appeal to a court on labour disputes.

\section{Settlement of labour disputes by the court in Uzbekistan:}

Statistical data on cases concerning labour disputes considered by the Civil Courts of the Republic of Uzbekistan: 


\begin{tabular}{|c|c|c|c|c|c|c|}
\hline & \multirow[b]{2}{*}{ Categories of labour disputes } & \multicolumn{5}{|c|}{2015} \\
\hline & & All cases & 总 & 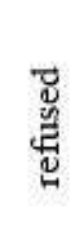 & 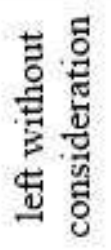 & 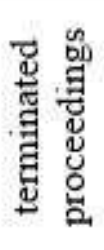 \\
\hline 1 & Reinstatement in Work & 1190 & 491 & 507 & 85 & 107 \\
\hline 2 & Recovery of earnings & 2328 & 2077 & 79 & 68 & 104 \\
\hline 3 & $\begin{array}{l}\text { Compensation of harm caused by } \\
\text { a worker to the employer } \\
\text { (subrogation) }\end{array}$ & 536 & 482 & 10 & 12 & 32 \\
\hline 4 & $\begin{array}{c}\text { Compensation of harm caused to } \\
\text { health of worker }\end{array}$ & 251 & 223 & 9 & 11 & 8 \\
\hline 5 & $\begin{array}{c}\text { Other cases related to labour } \\
\text { disputes }\end{array}$ & 258 & 120 & 51 & 27 & 60 \\
\hline & Overall & 4563 & 3393 & 656 & 203 & 311 \\
\hline
\end{tabular}

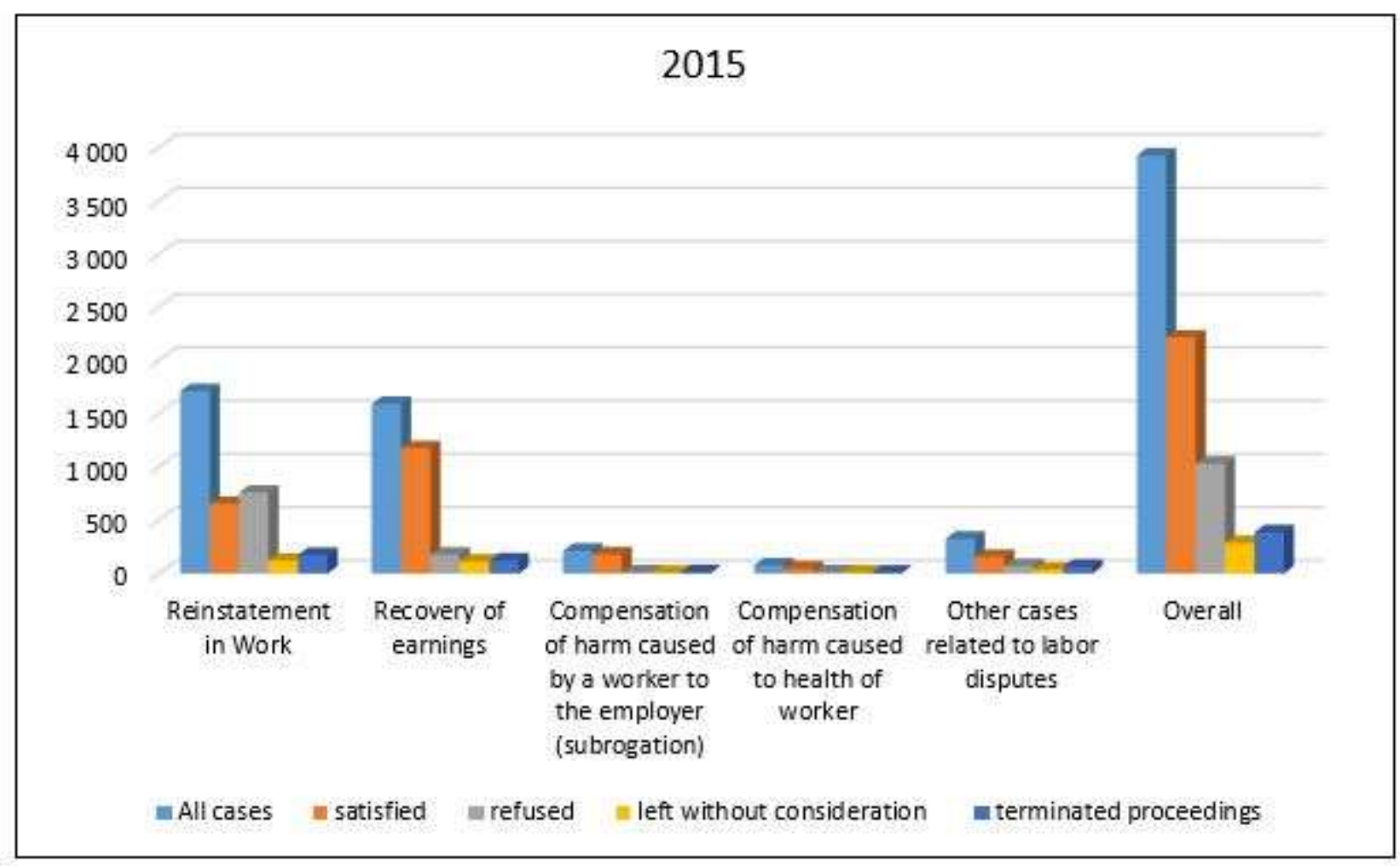




\begin{tabular}{|c|c|c|c|c|c|c|}
\hline & \multirow[b]{2}{*}{ Categories of labour disputes } & \multicolumn{5}{|c|}{2016} \\
\hline & & All cases & 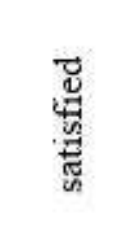 & 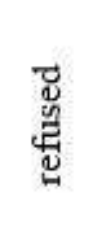 & 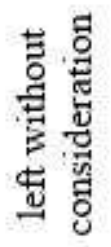 & 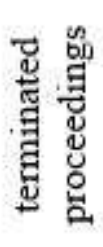 \\
\hline 1 & Reinstatement in Work & 1475 & 643 & 607 & 87 & 138 \\
\hline 2 & Recovery of earnings & 1782 & 1520 & 106 & 66 & 90 \\
\hline 3 & $\begin{array}{l}\text { Compensation of harm caused by a } \\
\text { worker to the employer } \\
\text { (subrogation) }\end{array}$ & 335 & 308 & 7 & 8 & 12 \\
\hline 4 & $\begin{array}{l}\text { Compensation of harm caused to } \\
\text { health of worker }\end{array}$ & 118 & 90 & 19 & 5 & 4 \\
\hline 5 & $\begin{array}{l}\text { Other cases related to labour } \\
\text { disputes }\end{array}$ & 331 & 199 & 67 & 21 & 44 \\
\hline & Overall & 4041 & 2760 & 806 & 187 & 288 \\
\hline
\end{tabular}

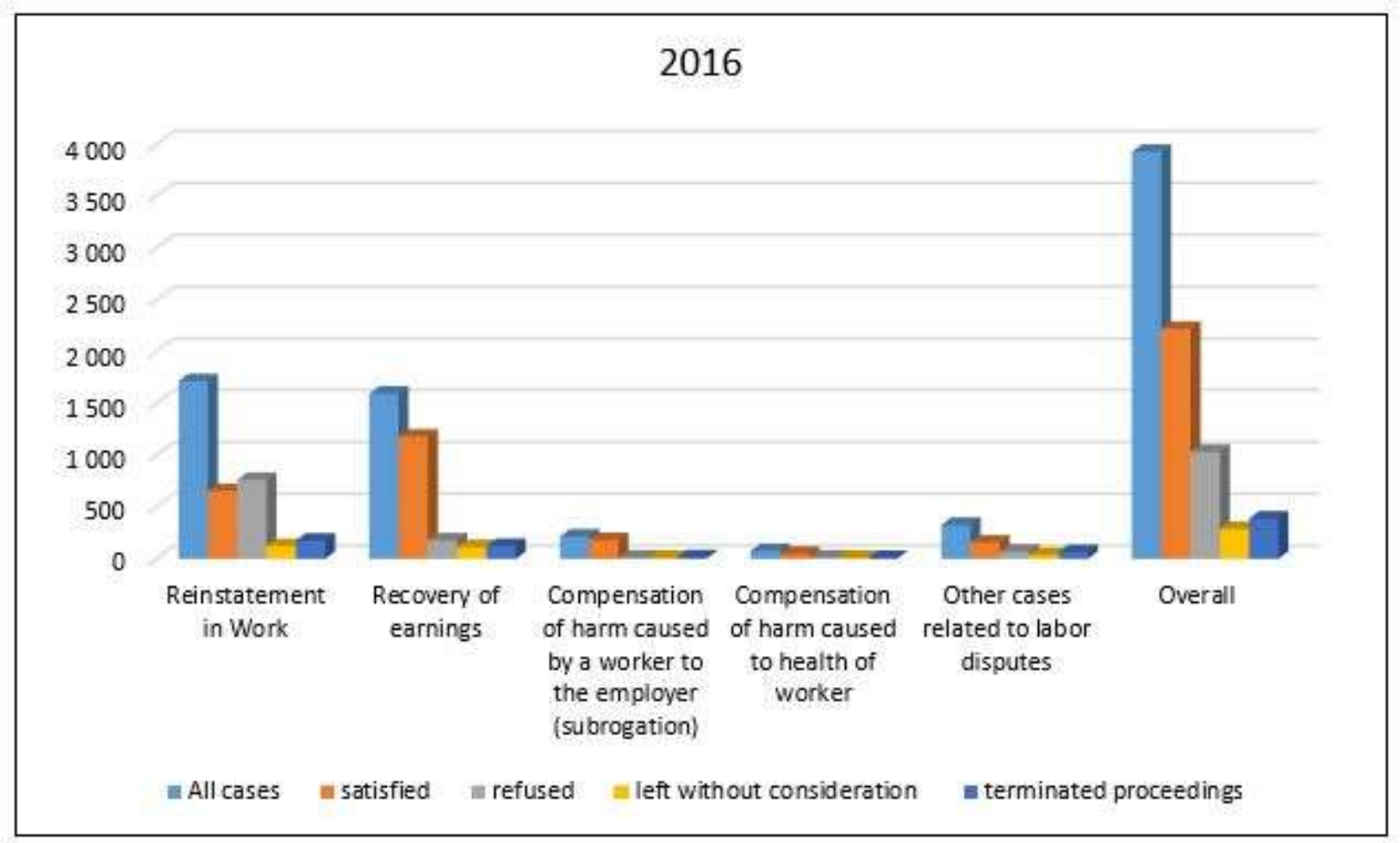




\begin{tabular}{|c|c|c|c|c|c|c|}
\hline & \multirow[b]{2}{*}{ Categories of labour disputes } & \multicolumn{5}{|c|}{2017} \\
\hline & & All cases & 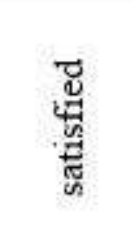 & 总 & 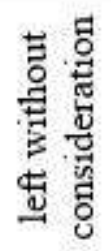 & 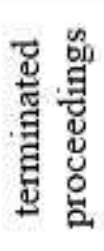 \\
\hline 1 & Reinstatement in Work & 1715 & 655 & 762 & 122 & 176 \\
\hline 2 & Recovery of earnings & 1594 & 1179 & 178 & 113 & 124 \\
\hline 3 & $\begin{array}{l}\text { Compensation of harm caused by a } \\
\text { worker to the employer } \\
\text { (subrogation) }\end{array}$ & 215 & 181 & 11 & 8 & 15 \\
\hline 4 & $\begin{array}{l}\text { Compensation of harm caused to } \\
\text { health of worker }\end{array}$ & 77 & 47 & 12 & 9 & 9 \\
\hline 5 & $\begin{array}{c}\text { Other cases related to labour } \\
\text { disputes }\end{array}$ & 327 & 157 & 70 & 35 & 65 \\
\hline & Overall & 3928 & 2219 & 1033 & 287 & 389 \\
\hline
\end{tabular}

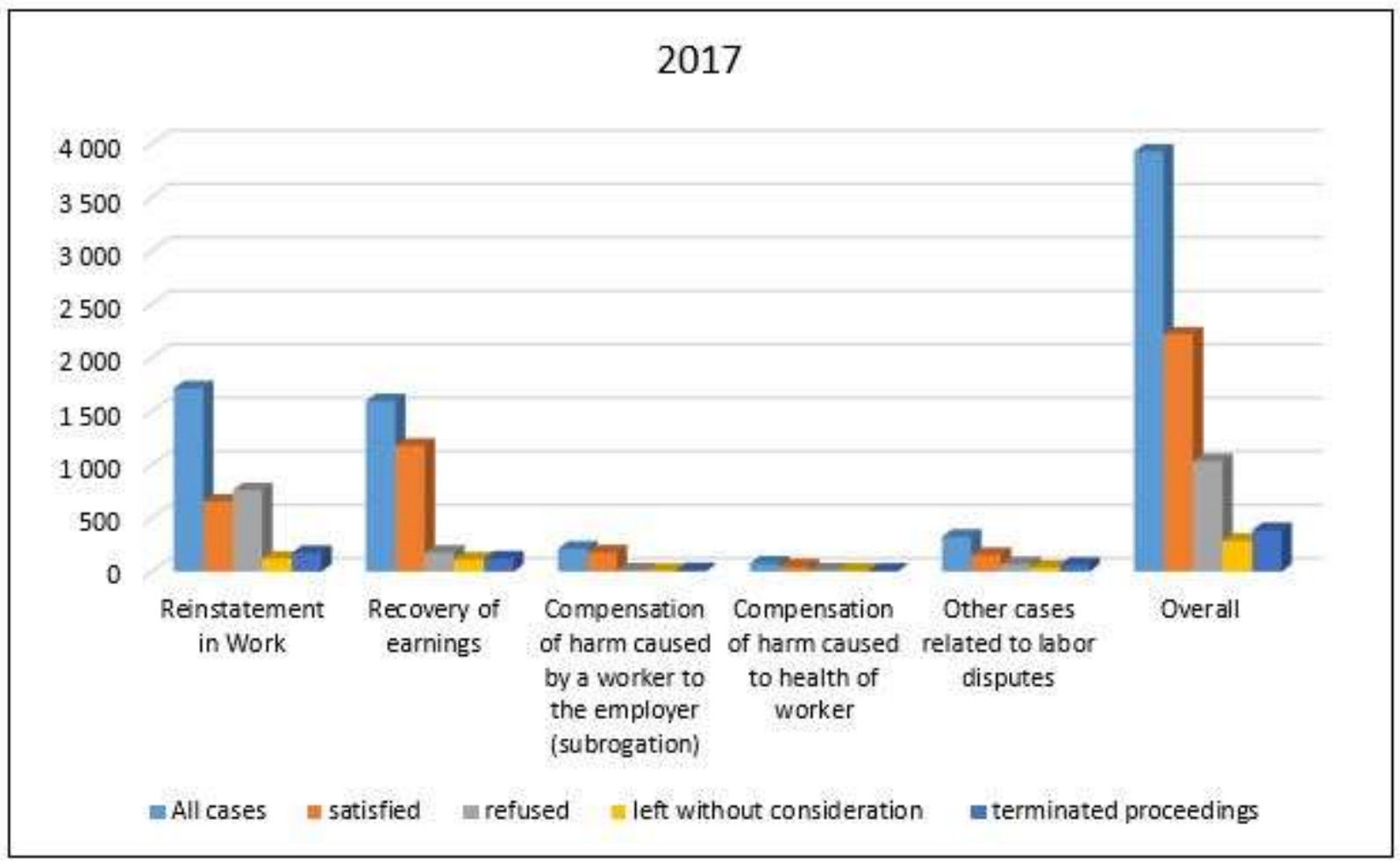




\begin{tabular}{|c|c|c|c|c|c|c|}
\hline & \multirow[b]{2}{*}{ Categories of labour disputes } & \multicolumn{5}{|c|}{2018} \\
\hline & & All cases & 壱 & 离 & 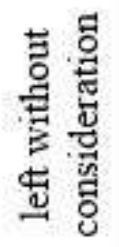 & 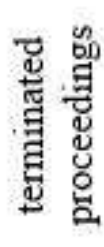 \\
\hline 1 & Reinstatement in Work & 1875 & 704 & 811 & 143 & 217 \\
\hline 2 & Recovery of earnings & 1903 & 1255 & 162 & 330 & 156 \\
\hline 3 & $\begin{array}{c}\text { Compensation of harm caused by a } \\
\text { worker to the employer } \\
\text { (subrogation) }\end{array}$ & 214 & 183 & 20 & 10 & 1 \\
\hline 4 & $\begin{array}{l}\text { Compensation of harm caused to } \\
\text { health of worker }\end{array}$ & 49 & 35 & 5 & 7 & 2 \\
\hline 5 & $\begin{array}{l}\text { Other cases related to labour } \\
\text { disputes }\end{array}$ & 744 & 280 & 79 & 182 & 203 \\
\hline & Overall & 4785 & 2457 & 1077 & 672 & 579 \\
\hline
\end{tabular}

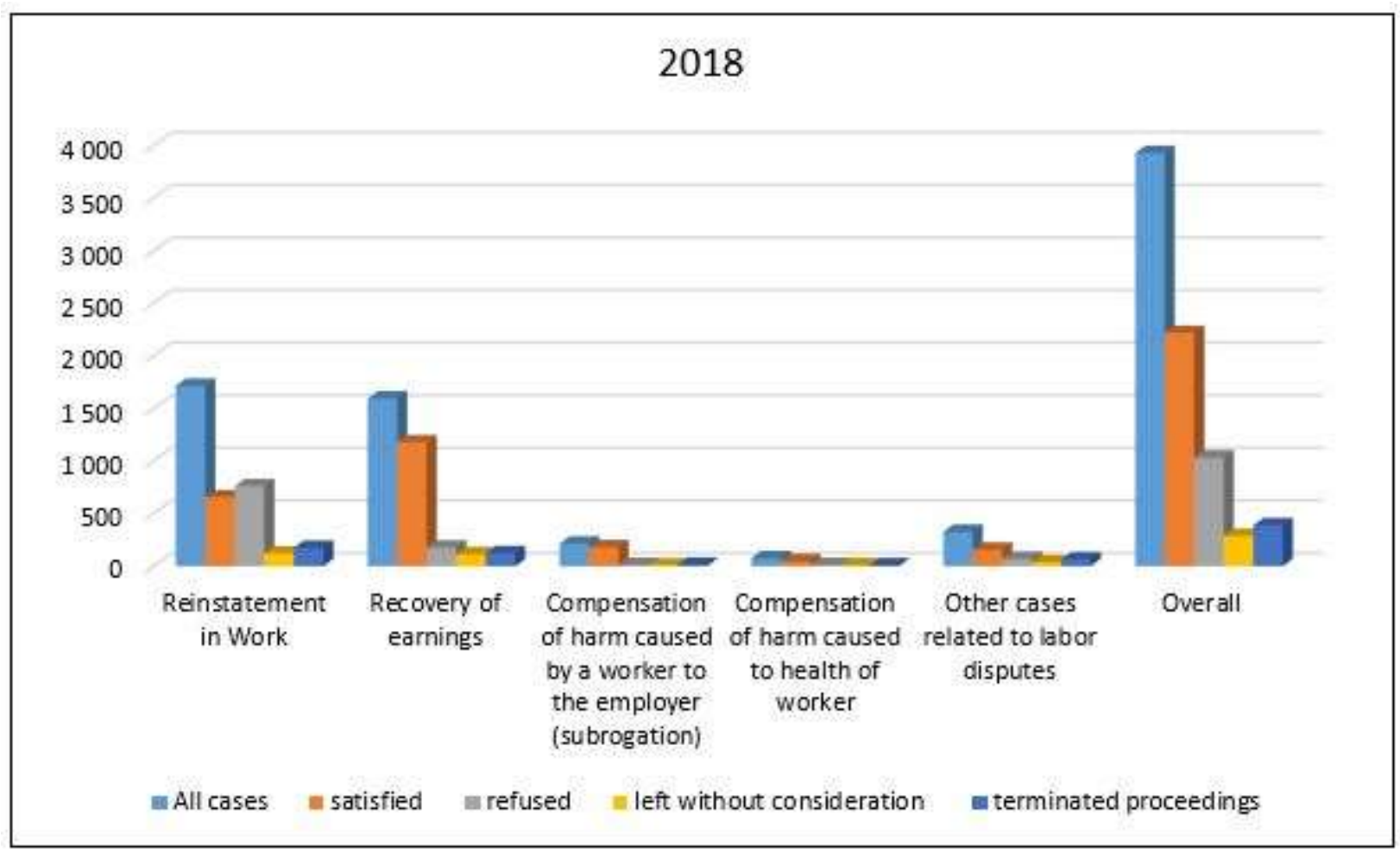




\begin{tabular}{|c|c|c|c|c|c|c|}
\hline & \multirow[b]{2}{*}{ Categories of labour disputes } & \multicolumn{5}{|c|}{2019} \\
\hline & & All cases & 总 & 总 & 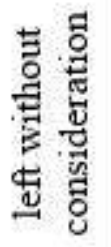 & 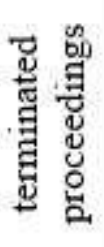 \\
\hline 1 & Reinstatement in Work & 1964 & 775 & 883 & 167 & 139 \\
\hline 2 & Recovery of earnings & 1279 & 873 & 133 & 229 & 44 \\
\hline 3 & $\begin{array}{c}\text { Compensation of harm caused by a } \\
\text { worker to the employer } \\
\text { (subrogation) }\end{array}$ & 196 & 144 & 23 & 20 & 9 \\
\hline 4 & $\begin{array}{c}\text { Compensation of harm caused to } \\
\text { health of worker }\end{array}$ & 94 & 60 & 14 & 12 & 8 \\
\hline 5 & $\begin{array}{c}\text { Other cases related to labour } \\
\text { disputes }\end{array}$ & 700 & 444 & 116 & 74 & 66 \\
\hline & Overall & 4233 & 2296 & 1169 & 502 & 266 \\
\hline
\end{tabular}

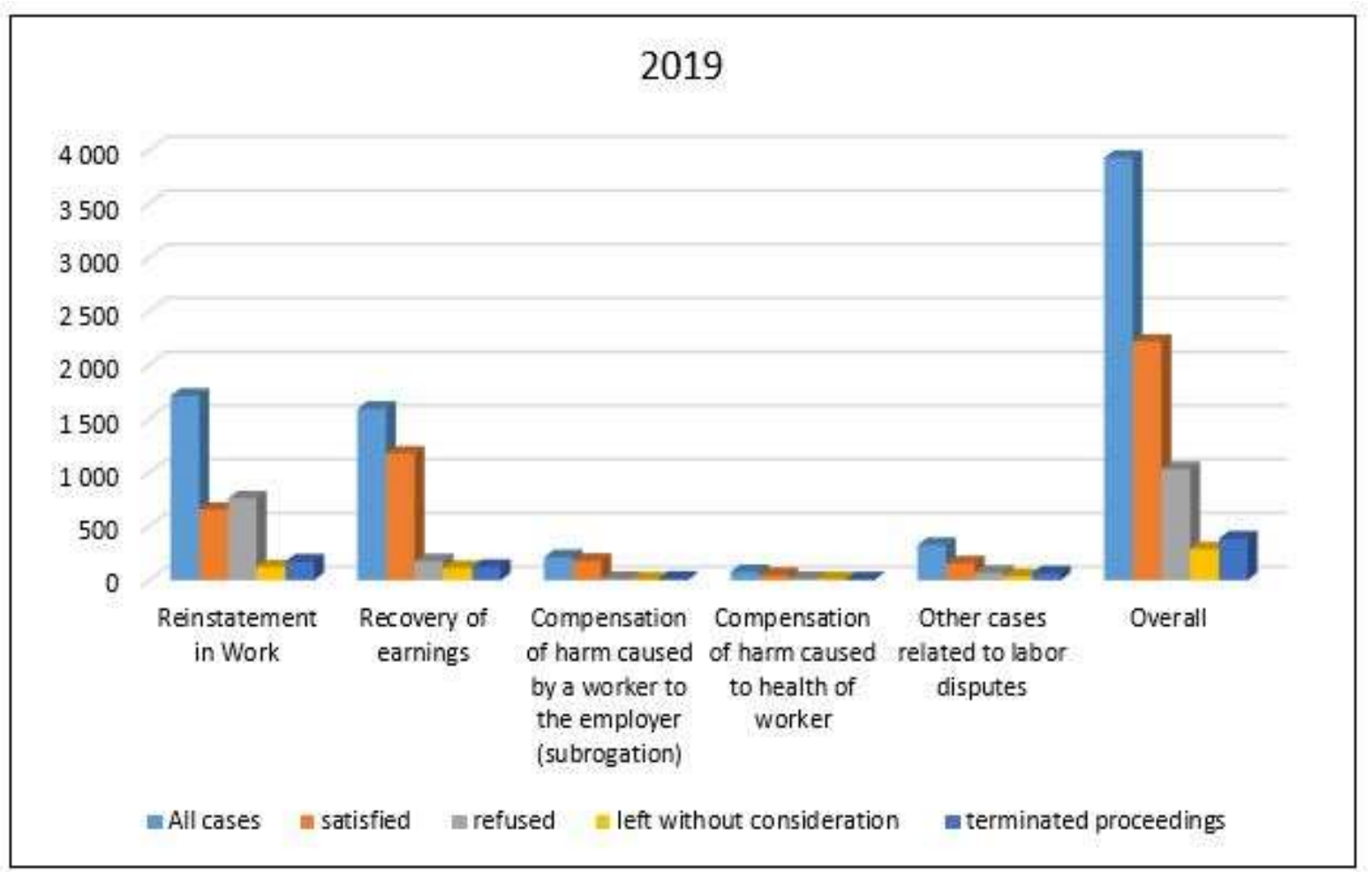




\begin{tabular}{|c|c|c|c|c|c|c|}
\hline & \multirow[b]{2}{*}{ Categories of labour disputes } & \multicolumn{5}{|c|}{2020} \\
\hline & & All cases & 芯 & $\begin{array}{l}\text { 己. } \\
\text { 岂 } \\
\text { 岕 }\end{array}$ & 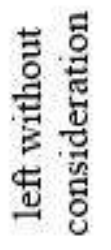 & 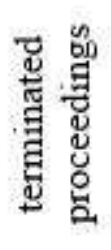 \\
\hline 1 & Reinstatement in Work & 1605 & 669 & 604 & 202 & 130 \\
\hline 2 & Recovery of earnings & 1243 & 966 & 117 & 121 & 39 \\
\hline 3 & $\begin{array}{c}\text { Compensation of harm caused by } \\
\text { a worker to the employer } \\
\text { (subrogation) }\end{array}$ & 72 & 59 & 3 & 8 & 2 \\
\hline 4 & $\begin{array}{c}\text { Compensation of harm caused to } \\
\text { health of worker }\end{array}$ & 54 & 40 & 6 & 5 & 3 \\
\hline 5 & $\begin{array}{c}\text { Other cases related to labour } \\
\text { disputes }\end{array}$ & 723 & 486 & 89 & 123 & 25 \\
\hline & Overall & 3697 & 2220 & 819 & 459 & 199 \\
\hline
\end{tabular}

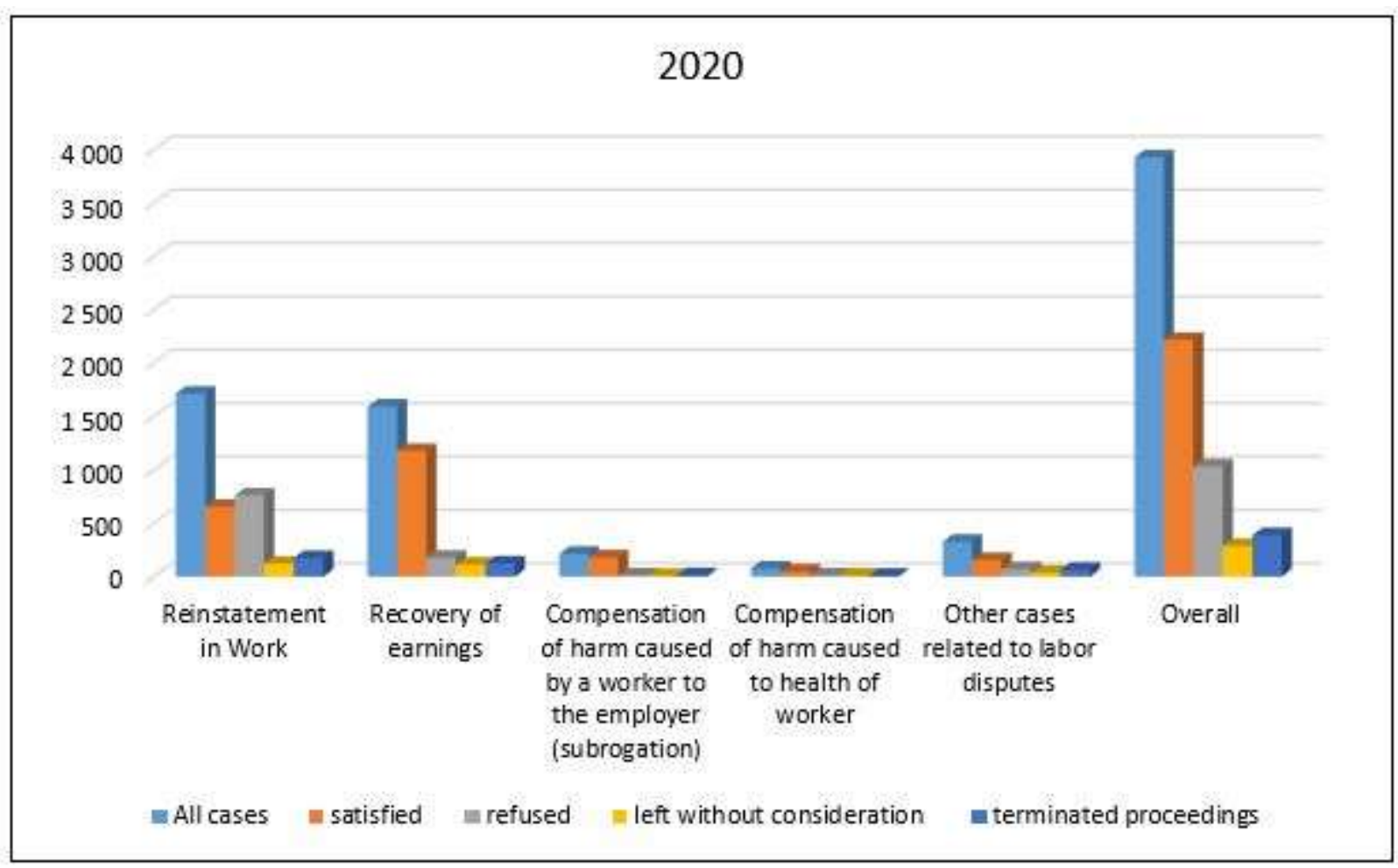

The Labour Code and Civil Code of the Republic of Uzbekistan regulate the procedure for settlement of the labour disputes by court.

According to the Information Service of State Committee of the Republic of Uzbekistan on Statistics, the permanent population of the Republic of Uzbekistan amounted to 34 million 191 thousand

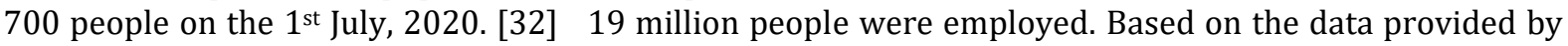
the State Committee on Statistics, we can conclude that dubiously, the number of labour disputes considered by the courts between 2015 and 2020 were less. (pay attention once again: the labour disputes considered by civil courts constituted 4563 cases in 2015, 4041 cases in 2016, 3928 cases in 2017, 4785 cases in 2018, 4233 cases in 2019 and 3697 cases during the 9 months in 2020). 
Undoubtedly, the aforementioned figures do not represent a clear indication of the labour disputes occurring among the 19 million employed.

A sufficiently short period of time to apply for the settlement of labour disputes in the labour legislation of the Republic of Uzbekistan is the main reason for such small number of labour disputes in jurisdictional courts. According to the Artice 270 of the Labour Code the following periods shall be established for application to a court or commission for labour disputes:

$>\quad$ with regard to disputes concerning reinstatement in work: one month from the date of handing a copy to the worker of the order concerning the termination of the labour contract with him;

$>\quad$ with regard to disputes concerning compensation of material harm by the worker caused to the employer: one year from the date of discovery by the employer of the harm caused;

$>\quad$ with regard to other labour disputes: three months from that day when the worker knew or should have known about the violation of his right.

With regard to disputes concerning compensation of harm caused to the health of a worker, the period for recourse to a court shall not be established. [33]

Deputy Minister of Employment and Labour Relations gave an interview to one of the official social networks on the following:

the total employed population in Uzbekistan has amounted 19 million people. 14 million people out of it do not know their labour rights. This situation causes very difficult condition to us.

Because senior staff are insignificantly paying attention to the labour rights of workers. Especially when it comes to private entrepreneurship. Today, the labour rights of two out of every three workers are being violated. This is a very big and bad figure. [34] According to the Deputy Minister, most employees and employers in Uzbekistan today do not know their labour rights and obligations. For an employee who intends to restore his or her violated labour rights, one or three months term is too short to appeal to Labour Disputes Commission or court.

\section{CONCLUSION}

The institute of labour disputes In Uzbekistan is under lack special attention. This indicates that the government is not pursuing an effective policy on the effictive use of economic and labour resources. Failure to consider and settle labour disputes in a timely way is raising a number of legal and practical matters in this field. To improve the effective settlement of labour disputes in the country, the following can be suggested for labour legislation and practice:

First, the role of labour law in social relations is insufficient today due to the scarcity of jobs and high level of staff turnover in the labour market of Uzbekistan. The development of the Uzbek economy and the expansion of sustainable jobs will undoubtedly contribute to increasing the level of compliance with labour laws among the population.

Second, the procedure for settling labour disputes on the territory of the enterprise, namely the work of the Labour Disputes Commission should be revived. This not only saves the disputing parties from unnecessary expenses, but also prevents them from wasting their valuable time. As a result, the workers will not encounter to financial losses due to saving their time instead of going to the court.

Third, one of the most important tasks of the government is to thoroughly improve the legal literacy of the population in Uzbekistan. In our view, in order to achieve this result in the next decade, the country must implement the following:

it is necessary to develop and effectively implement methodological programs that teach children to imitate participation in labour relations in kindergartens by organizing various psychological games.

Furthermore, school curriculum should include some subjects that teach labour law rules, the rights and obligations of the subjects in labour relations in the elementary form. This will positively effective on improving the literacy of the population.

The legal literacy of the population can also be increased by further expanding the system of higher law education. Moreover, students of non-legal specialists should also be given the opportunity to study labour law. This can be provided through the special subjects included in the curriculum.

Fourth, the guidelines for settling labour disputes through mediation shoulde be promoted among the population. To achieve this, the government should take measures to provide financial incentives to the population who have voluntarily used the help of a mediator to settle the dispute. Such policy should be pursued until the settlement of disputes through mediation becomes widespread among the population. Many lawyers in Uzbekistan today know that a mediator can resolve all legal disputes quickly and efficiently. For example, according to the judges of the Supreme Court of the Republic of Uzbekistan H. Yodgorov, G. Ziganshina, Sh. Akhatova, the settlement of labour disputes in court is often not the most appropriate means of resolving the dispute for the parties. Because it has high amount of costs, and may breach personal and business relationships. In addition, the conflict may lead to unwanted 
disclosure of circumstances. Therefore, it is important to introduce the institution of mediation in the practice of conflict resolution. [35]

Uzbekistan should ratify the ILO Recommendations № 92 and № 130. Because most of the provisions of these Recommendations are reflected in the national labour legislation of Uzbekistan. Undoubtedly, when they are ratified, they will contribute to the further improvement of the national labour system. Over the next 10 years, Uzbekistan must take measures to effectively use alternative labour disputes resolution.

\section{REFERENCES}

1. Minawa Ebisui, Sean Cooney, Colin Fenwick. Resolving Individual Labour Disputes. A comparative $\begin{array}{lllll}\text { overview. International } & \text { Labour } & \text { Organization. } & 2016 & \text {.p-20 }\end{array}$ Available:https://www.ilo.org/wcmsp5/groups/public/---dgreports/---dcomm/--publ/documents/publication/wcms_488469.pdf

2. The company Eenter Engineering commented on the incident on one of its property. Available: http://minenergy.uz/uz/news/view/874

3. Law of the Republic of Uzbekistan on Mediation. Available: https://lex.uz/docs/3805227

4. Decree of the President of the Republic of Uzbekistan on Measures for further improvement of mechanisms for Alternative Dispute Resolution Available:https://lex.uz/docs/4859436

5. Mostovshikov A.A. The procedure for considering individual labor disputes. Thesis for a candidate of legal sciences. Tomsk. 2004 pp. 34

6. Cooperation with International Labor Organization // Available: http://old.mehnat.uz/cyrl/page/xalqaro-mehnat-tashkiloti-bilan-hamkorlik

7. Minawa Ebisui, Sean Cooney, Colin Fenwick. Resolving Individual Labour Disputes. A comparative overview. International Labour Organization. 2016. p-5 Available: https://www.ilo.org/wcmsp5/groups/public/---dgreports/---dcomm/--publ/documents/publication/wcms_488469.pdf

8. Labour Code of the Russian Federation. Available: http://base.garant.ru/12125268/

9. Labor Code of the Republic of Kazakhstan. https://online.zakon.kz/document/?doc_id=38910832

10. Labor Code of the Republic of Tajikistan. Available: chromeextension://ohfgljdgelakfkefopgklcohadegdpjf/https://www.ilo.org/dyn/natlex/docs/ELECTRONIC /106793/131157/F1553040433/Labor\%20Code\%20Tajikistan\%20Eng\%20February\%202017\%2 0n.pdf

11. Labor Code of the Republic 2. Labor Code of the Kyrgyz Republic // Available: chrome-
19 extension://ohfgljdgelakfkefopgklcohadegdpjf/file:///C:/Users/User/Downloads/KGZ73094\%20Ru ssian.pdf

13. Labor Code of the Republic of Belarus // Available: https://www.ilo.org/dyn/natlex/natlex4.detail?p_lang=en\&p_isn=73094

14. Labor Code of Ukraine // Available: https://www.ilo.org/dyn/natlex/docs/ELECTRONIC/46087/120195/F872065769/

15. Labor Code of the Republic of Uzbekistan // Available: https://lex.uz/docs/142859

16. Labor Code of the Republic of Azerbaijan // Available: https://online.zakon.kz/Document/?doc_id=30420364\#pos=6;-106

17. Law of the Republic of Uzbekistan on Mediation. Available: https://lex.uz/docs/3805227

18. Tursunov Y. Commentary to the Labor Code of the Republic of Uzbekistan. Adolat. 2018. P- 728

19. Data from the response letter submitted to the Tashkent State Law University on the fact that the Labor Disputes Commission of the Ministry of Employment and Labor Relations of the Republic of Uzbekistan did not see any labor disputes between 2015-2020.

20. Gontsov I.N. Methods for resolving labor disputes in the Russian Federation. / Bulletin of Perm University // Available: https://cyberleninka.ru/article/n/sposoby-razresheniya-trudovyh-sporovv-rossiyskoy-federatsii/viewer

21. Minawa Ebisui, Sean Cooney, Colin Fenwick. Resolving Individual Labour Disputes. A comparative overview. International Labour Organization. 2016. p-125 Available: https://www.ilo.org/wcmsp5/groups/public/---dgreports/---dcomm/--publ/documents/publication/wcms_488469.pdf

22. Draft Law of Ukraine No. 3665 On Mediation. Available: https://mediationeurasia.pro/zakonodatelstvo/proekt-zakona-ukrainy-3665-o-mediacii 
23. Gontsov I.N. Methods for resolving labor disputes in the Russian Federation. / Bulletin of Perm University

24. Federal Law of the Russian Federation On alternative dispute resolution procedure (mediation procedure) // Available: https://mediation-eurasia.pro/zakonodatelstvo/federalnyj-zakonrossijskoj-federacii-ob-alternativnoj-procedure-uregulirovanija-sporov-procedure-mediacii-193-fz

25. Law of the Republic of Kazakhstan On Mediation// Available: https://mediationeurasia.pro/zakonodatelstvo/zakon-respubliki-kazahstan-o-mediacii

26. Decree of the Ministry of Justice of the Republic of Belarus No. 15 On approval of the Mediator's Ethics Rules// Available: https://mediation-eurasia.pro/zakonodatelstvo/postanovlenieministerstva-justicii-respubliki-belarus-15-ob-utverzhdenii-pravil-jetiki-mediatora

27. Law of the Republic of Moldova No. 137 On Mediation// Available: https://mediationeurasia.pro/zakonodatelstvo/zakon-respubliki-moldova-137-o-mediaci

28. Law of the Kyrgyz Republic No. 161 On Mediation // Available: https://mediationeurasia.pro/zakonodatelstvo/zakon-kyrgyzskoj-respubliki-161-o-mediacii

29. Constitution of the Republic of Uzbekistan// Available: http://constitution.uz/uz/clause/index

30. New text of the Constitution of the Russian Federation with the 2020 amendments// Available: http://duma.gov.ru/news/48953/

31. Constitution of the Republic of Kazakhstan // Available: https://www.akorda.kz/ru/official_documents/constitution

32. The number of permanent population of Uzbekistan has been announced // Available: https://review.uz/oz/post/ozbekistonning-doimiy-aholisi-soni-malum-qilindi

33. Labor Code of the Republic of Uzbekistan // Available: https://lex.uz/docs/142859

34. Deputy Minister of Employment and Labor Relations gave an interview to one of the official social networks.// Available: https://kun.uz/news/2020/12/07/ozbekistonda-14-mln-kishi-oz-mehnathuquqlarini-bilmaydi-vazir-orinbosari

35. Yodgorov X, Ziganshina G, Axatova Sh. Disputes arising from labour relations. Practical guide. 2017. 